beautiful trees which will become the living monuments of people's love for Nature.

Apart from this we also conduct regular training programmes on environmental conservation to college and school students. Through this we reckon to have trained another 50,000 students who, in turn, act as agents of environmental conservation in their own areas. Each student plants 10 saplings and follows their growth regularly, thus contributing to afforestation programmes in the areas where they live.

\section{A Request}

So far we have been able to contribute only a small fraction to the stupendous task of protecting our environment. We believe that, by training and educating students and rural people, we will be able to build a better world for future generations.

We have been able to do all this with the meagre funds available to us and with the help of some donations. We would greatly appreciate contributions from Nature lovers to help us to carry on our work.

SAVARI IGNACIMUTHU
Development Wing, SHEPHERD,
St Joseph's College (Autonomous)
Tiruchirapalli 620002
India.

\title{
Need of Universal Legislation to Protect Global Freshwater Supplies
}

We are appealing to you to invoke universal legislation to protect the world's fast-diminishing supplies of available fresh water. This, perhaps most valuable and utterly indispensable of all the Earth's natural resources, is fast being undermined by irresponsible governments allowing overexploitation, wastage, and pollution.

Here, on the Capricorn Coast of Central Queensland, we have a permanent and hitherto reliable freshwater supply, provided by a continuous flow from the high-dunes of Shoalwater and Byfield. But we are in an intolerable position where both State and Federal governments are intent on allowing two companies - one of them foreignowned, the other foreign-funded - to sandmine this water catchment and dunal reservoir of fresh water.

Our governments do not appear to realize that a region cannot function without a reliable water-supply; nor will they admit and face up to the possible consequences of the loss or depletion of that water-supply.

The federal government has ignored all expert advice and scientific evidence, and has chosen to grant leases in the Shoalwater Bay Military Training Area on the basis of only a single, biassed environmental impact statement (EIS). Federal ministers ignored environmental legis- lation and failed to comply with the terms of the pertinent Act. The State government is about to embark on the same farcical EIS process to achieve their ends in the Byfield National Park.

When global freshwater supplies are fast diminishing as a result of human impact and widespread abuse, not to mention the foreseeable effects of expected climate change, why would the world's driest continent deliberately destroy this most valuable of all its natural resources? We can only suspect some sinister motive of general or personal greed.

We call on your organization to protect the world's vital freshwater supplies and catchment areas, by pressing for universal legislation whereby governments are held accountable and responsible to international laws enacted for the general good.

ROBIN HEALY, Vice-President
Wildlife Preservation Society
Queensland-Capricorn Branch
Environment Centre
PO Box 263
Yeppoon
Queensland 4703
Australia.
Wildlife Preservation Society Queensland-Capricorn Branch Environment Centre PO Box 263 Queensland 4703 Australia.

\section{Nigeria's Forests Gain from New National Park*}

\section{Introduction}

In an effort to preserve two of the country's remaining large tracts of rain-forest, the Nigerian Government has announced the creation of a major new national park. The Cross River National Park in southeastern Nigeria established with the help of WWF-UK - will be situated alongside ecologically identical park areas in neighbouring Cameroon. Together they will include areas of rich biological diversity, with more species per square kilometre than almost any other moist equatorial forest in the world. The scheme represents a regional initiative to conserve valuable ecosystems and ecocomplexes, and the areas are also important for protecting the watershed in Cameroon and Nigeria.

The Oban Hills section of the new Park lies south of the Cross River, which 'snakes across the belly' of Cross River State. It merges with Korup National Park in Cameroon where a WWF programme is already under way. The Boshi-Okwangwo section to the north of the river lies next to Takamanda Forest Reserve, where protection measures are already being introduced. Together the areas formed part of a moist forest refuge during the

\footnotetext{
* Adapted, with appreciation, from WWF Features. — Ed.
}

Pleistocene period, and have therefore experienced a prolonged period of uninterrupted evolutionary activity,' explains Peggy Allcott, WWF-UK's Conservation and Development Officer for Cameroon and Nigeria, continuing 'Oban (3,000 sq. $\mathrm{km})$ and Korup (3,500 sq. $\mathrm{km})$ will be one of the largest and most important conservation units in moist equatorial forests, and [together will] contain more kinds of plants and animals per square kilometre than almost any other in Africa or [indeed] the world.'

\section{Implementation}

Overall, the scheme is expected to cost between US $\$ 55 \mathrm{M}$ and US $\$ 60 \mathrm{M}$ over the next seven years. Funding for the development of the Park plan, and for the work so far, has been with support from the European Economic Community (EEC) and Overseas Development Administration (ODA). The EEC has also agreed to fund its implementation in the Oban Hills sector of the Park, but funding for the Boshi-Okwangwo sector has yet to be secured.

At the request of the Nigerian Federal and Cross River State authorities, a detailed plan for the Park was drawn up by WWF-UK with the help of a team of environmental consultants. The team conducted surveys in the field to identify current patterns, constraints, and potentiality, of 